\title{
Tax policy and innovation: A search for common ground
}

\author{
Jerry Courvisanos*, Anthony J. Laramie ${ }^{* *}$ \\ and Douglas Mair ${ }^{* * * * * * *}$
}

\begin{abstract}
The paper is motivated by a desire to find common ground between mainstream and post-Keynesian approaches to fiscal policy. A post-Keynesian approach with origins in Kalecki offers a promising line of enquiry which is developed here. The paper identifies the principal differences between the Keynesian and Kaleckian approaches. The possibilities are explored of finding accommodation between the mainstream and Kaleckian approaches to the taxation of greenhouse gases. The macroeconomic implications of taxing greenhouse gases are identified. However, these may be thwarted by the emergence of 'political aspects of innovation, akin to Kaleckis spolitical aspects of full employmentr. A Kaleckian balanced budget approach allied to fiscal incentives to innovate offers some prospect of common ground with the mainstream.

JEL classification: $\mathrm{H}_{20} \mathrm{O} \mathrm{H}_{22}, \mathrm{H}_{23}$

Keywords: tax policy, innovation, greenhouse gases, post-Keynesian mainstream
\end{abstract}

* University of Ballarat, Australia.

** Merrimack College, USA.

*** Heriot-Watt University, UK.

**** We wish to thank Eckhard Hein and an anonymous referee for helpful comments on an earlier draft.

Correspondence Address:

Professor emeritus Douglas Mair, School of Management and Languages, Heriot-Watt University, Edinburgh EHI4 4AT, United Kingdom, e-mail: dmair3639@hotmail.com.

Received I3 January 2009, accepted 26 June 2009

(C) INTERVENTION 6 (2), 2009, 27I-287 


\section{Introduction}

The themes of the 2008 Research Network Macroeconomics and Macroeconomic Policies conference are to examine the changes that are taking place in mainstream economics; to establish what, if any, is the new orthodoxy; and to identify the implications for post-Keynesian economics. In particular, the conference organisers have asked contributors to examine the role of fiscal policy in both mainstream and post-Keynesian macroeconomics with a view to establishing whether there is any possible common ground between them. This is the task we have set ourselves in this paper. In what follows we distinguish two categories of post-Keynesian economics. The category that has its origins in Keynes we designate as post-Keynesian (JMK). The category that has its origins in Kalecki we designate as post-Keynesian (MK).

In a sense, our task is a 'mission impossible because the principal emphasis of mainstream macroeconomics is on monetary policy, denying any substantive role for fiscal policy, except possibly in times of severe recession. On the other hand, the principal emphasis of post-Keynesian (JMK) macroeconomics is on fiscal policy, rejecting many of the mainstream criticisms of fiscal policy as groundless or irrelevant. For as long as mainstream and post-Keynesian (JMK) economics maintain their entrenched stances, we see little prospect of a meaningful dialogue emerging between them. Rather than sit uncomfortably sandwiched between Scylla and Charybdis, ${ }^{\text {I }}$ we concentrate on an area in which mainstream economics recognises that fiscal policy, in particular tax policy, has an important, perhaps critical, role to play, namely, the control of greenhouse gas emissions and show how postKeynesian (MK) economics may provide common ground on which a useful dialogue may take place. In the mainstream view, taxes on greenhouse gases are usually intended to correct for negative externalities by changing relative prices, and, in so doing affect the aggregate level of economic activity. In the post-Keynesian (MK) approach, greenhouse gas taxes have both short-period and long-period effects that will be considered below.

The following is in seven sections. In Section 2 we review briefly the current mainstream stance on fiscal policy. In Section 3 we discuss the dominant post-Keynesian (JMK) approach. In Section 4 we identify the main features of the post-Keynesian (MK) approach to fiscal policy that distinguish it from the post-Keynesian (JMK) approach. In Section 5 we discuss the role of taxation in a Kaleckian growth model. In Section 6, we demonstrate how a Kaleckian approach to the taxation of greenhouse gas emissions can influence the rate of innovation. In Section 7, we show how policy measures to stimulate innovation may be thwarted by a political innovation cycle. Finally, in Section 8 , we consider what common ground there may be between mainstream and post-Keynesian (MK) economics on the interaction between tax policy and innovation.

I In Homer's The Odyssey, Odysseus had to navigate between these two natural elements, monster and whirlpool respectively, that threatened the ship. Similarly we need to navigate between two opposing schools of thought. 


\section{Role of tax policy in the mainstream fiscal policy stance}

Contemporary mainstream macroeconomics identifies itself as the New Economic Consensus (NEC) and is an amalgamation of the developments in macroeconomics from the post-war neo-Classical Synthesis to the present day. Its defining characteristic is the claim that choice-theoretic micro-foundations determine macroeconomic outcomes. In order to explain aggregate employment and output, all macroeconomic models must, according to the NEC, incorporate individual inter-temporal decision-making based on rational expectations. Within this framework, however, there are still disagreements as to the role of fiscal policy (Tcherneva 2008).

Having virtually abandoned fiscal policy during its monetarist phase, there are now influential voices within NEC that recognise it may have a limited role to play (Bernanke et al. 2004, Krugman 2005). This concession stems from recognition that there may be circumstances, for example when the short-term rate of interest falls to zero, under which no further economic stimulus from monetary policy is possible. However, within the NEC coterie, fiscal policy is viewed very much as a measure of last resort to be used only in periods of extreme deflation despite its distortive and inflationary effects. It is now accepted by Bernanke (2003a), among others, that in the short run fiscal authorities may have important reasons for deviating from a balanced budget (or budget surplus) stance when faced with national emergencies or deep recessions (e.g. the 2008 global financial crisis). In the long run, however, the fiscal disciplines of the balanced budget and responsible levels of national debt must be maintained.

An important feature of the emerging NEC stance on fiscal policy is that the Ricardian equivalence hypothesis which had previously precluded fiscal policy effectiveness may not hold. This opens the possibility that wealth effects from deficit spending may affect aggregate demand. Abandonment of Ricardian equivalence raises the fear that governments may lose financial discipline and incur ever-rising debts. Sustainability of a government's budget is a major concern for NEC economists. The NEC overwhelmingly subscribes to the doctrine of sound financer to avoid the distortive and inflationary effects of government spending. The dominant NEC view is that the principal goal for fiscal policy is to avoid an intolerable tax burden on future generations. The inter-temporal budget constraint is an important underlying condition for understanding the role of fiscal policy from a NEC perspective.

There is widespread agreement in the NEC that fiscal policy is inherently inflationary and that its use should be restricted to deflationary conditions. At all other times, monetary policy should dominate and fiscal policy should remain passive and be automatic, transparent, credible and rule-compliant. There is a strong supply-side predilection in the NEC so that if fiscal policy is deemed necessary it should take the form of tax cuts and not increases in government spending.

The final issue we consider is the NEC view of the link between fiscal policy and full employment. The NEC dynamic general equilibrium model does not admit the existence of involuntary unemployment. This marks a complete break from Keynes whose revolutionary raison d'être was to find a cure for involuntary unemployment. 
This necessarily brief summary of the NEC stance on fiscal policy confirms that except under the direst of circumstances it is to be avoided like the plague, bringing with it as it does all sorts of unwelcome complications such as inflation and resource misallocation. For the NEC s sound financer and balanced budgets are the sine qua non of responsible macroeconomic fiscal policy. There is, however, one important area in which the NEC sees positive merit in fiscal policy and that is the area of climate change where the use of taxes is advocated as an important instrument in controlling the levels of greenhouse gases into the atmosphere (Stern 2006). We return to this issue in more detail in Section 6 below.

\section{Post-Keynesian (JMK) Stance on Fiscal Policy}

The post-Keynesian (JMK) camp takes a diametrically opposite view of the role of fiscal policy. In terms of achieving macroeconomic coordination and stabilisation objectives, postKeynesians (JMK) such as Arestis and Sawyer (2004) see fiscal policy as a more potent instrument than monetary policy, although, surprisingly, they give little credit to Kalecki's contribution. Post-Keynesian (JMK) analysis revives Lerner's (I943) functional finance approach in which fiscal policy is to be judged not by ex-post budgetary results but by its real effects on the economy. Governments face no limits to their spending and the role of fiscal policy is to spend as much as is necessary to bring the economy to full employment. Although Arestis and Sawyer identify a number of NEC assumptions that undermine fiscal policy effectiveness, they argue that the post-Keynesian (JMK) functional finance approach is not necessarily inconsistent with the NEC. They reject crowding out and add to the criticisms of the Ricardian equivalence hypothesis.

The type of fiscal policy advocated by post-Keynesians (JMK) is one that encourages investment and growth. For example, Arestis and Sawyer write:

„Fiscal policy of the sunctional financer type boosts aggregate demand, and thereby has a stimulating impact on investment, which raises the future productive capacity of the economy $[\ldots]$. The growth rate may thereby be favourably enhanced by fiscal policy." (Arestis/Sawyer 2004: 139)

This version of the post-Keynesian (JMK) functional finance approach stimulates investment and growth and aims to reduce the demand gap. It is not dependent on any particular type of public spending or investment. These are critical issues to which we return in more detail below. The main virtue of this post-Keynesian (JMK) approach is that it always raises aggregate demand, unlike in the NEC where fiscal policy only has demand side effects in non-Ricardian regimes.

For both the NEC and the post-Keynesians (JMK), the barrier to attaining full employment is inflation although the latter have a different interpretation of inflation. Post-Keynesians (JMK) see no single NAIRU (Non-Accelerating-Inflation-Rate-of-Unemployment) but rather a fluctuating structuralist inflation barrier whose level depends on a number of factors such as capacity utilisation and the rate of growth of capital stock. With a fluctuat- 
ing inflation barrier, ,full employment is given by the employment level when aggregate demand hits this barrier. Thus, a number of levels of full employment exist depending on the level of aggregate demand and the location of the inflation barrier.

The principal feature of the post-Keynesian (JMK) approach is its belief in the effectiveness of fiscal policy which contrasts with its relative ineffectiveness in the NEC view. The post-Keynesian (JMK and MK) approaches reject the crowding out effect, Ricardian equivalence, and the fixed supply assumptions of the NEC. Whereas the NEC treats the growth rate as given, in the dynamic post-Keynesian (JMK) approach as advocated by Arestis and Sawyer, growth rates will change in response to changes in government spending so that fiscal policy need not run into traditional budget constraints. In contrast to the NEC, both post-Keynesian approaches consider the aggregate income/output and employment effects of broad based taxes, like greenhouse taxes, through channels other than the traditional supply-side channels of NEC.

\section{Fiscal policy: Keynes or Kalecki?}

The ghost of Keynes is present at both the NEC and post-Keynesian (JMK) feasts. The NEC is determined to exorcise it once and for all while post-Keynesians (JMK) are keen to resuscitate it. However, Keynesian fiscal policy is not the only post-Keynesian game in town. Kalecki has at least as strong a claim as Keynes as the founder of post-Keynesian economics (Harcourt 2006) and a stronger claim for primacy on the role of tax policy (Asimakopulos 1978). Kalecki (1937) recognised that the publication of Keynes' General Theory required a whole new approach to the study of taxation. He worked through the short-period macroeconomic effects of taxes on commodities, incomes and capital but never explicitly incorporated taxation into his subsequent dynamic analyses. Asimakopulos and Burbidge (1974) published a fully developed short-period Kaleckian model. Laramie and Mair (2000) integrated Kalecki's theories of taxation, income distribution, income determination, investment, business cycle and growth.

There are a number of important, and sometimes subtle, differences between Keynesbased and Kalecki-based approaches to fiscal policy which we summarise using five concepts in italics below.

Balanced budget. Both the post-Keynesian (JMK) and the post-Keynesian (MK) approaches identify the macroeconomic short-period effects within a balanced budget regime without requiring any changes to aggregate government taxation or spending. In the JMK approach, the effect of a balanced budget tax change, and, therefore, the size of the balanced budget multiplier depends on relative propensities to save of those being taxed or those receiving transfers. For example, a redistributive balanced-budget tax is a tax on high-income groups (with high propensities to save), balanced against transfers to low-income groups (with low propensity to saves). The net effect stimulates aggregate demand.

In the MK approach, the effects of balanced budget changes in taxes on aggregate income/output and employment depend primarily on how the tax change affects aggregate 
pre-tax profits as national income is pushed up to a level so that pre-tax profits are realised. Kalecki showed that post-tax profits (the sum of profits after taxes plus profit taxes) equal the sum of private investment, the government budget deficit, the trade surplus, and consumption out of profits less savings out of wages. Given that the wage share is determined by the degree of monopoly as reflected in price/prime costs mark-ups, inter alia, the aggregate level of income is pushed up to the point where pre-tax profits, as described before, are realised, and the wage bill is paid. If changes in wage taxes are shifted, business mark-ups will fall, and higher levels of national income and employment will be required for aggregate profits to be realised. If changes in profits taxes are shifted, business mark-ups will increase, and a lower level of national income will be required for aggregate profits to be realised. An increase in the profits tax balanced against a decrease in the wage tax, leads to an increase in short-period pre-tax profits, national income and employment.

Figure Ia: The incidence and effects of taxation - An increase in wage taxes (short-period effects)*

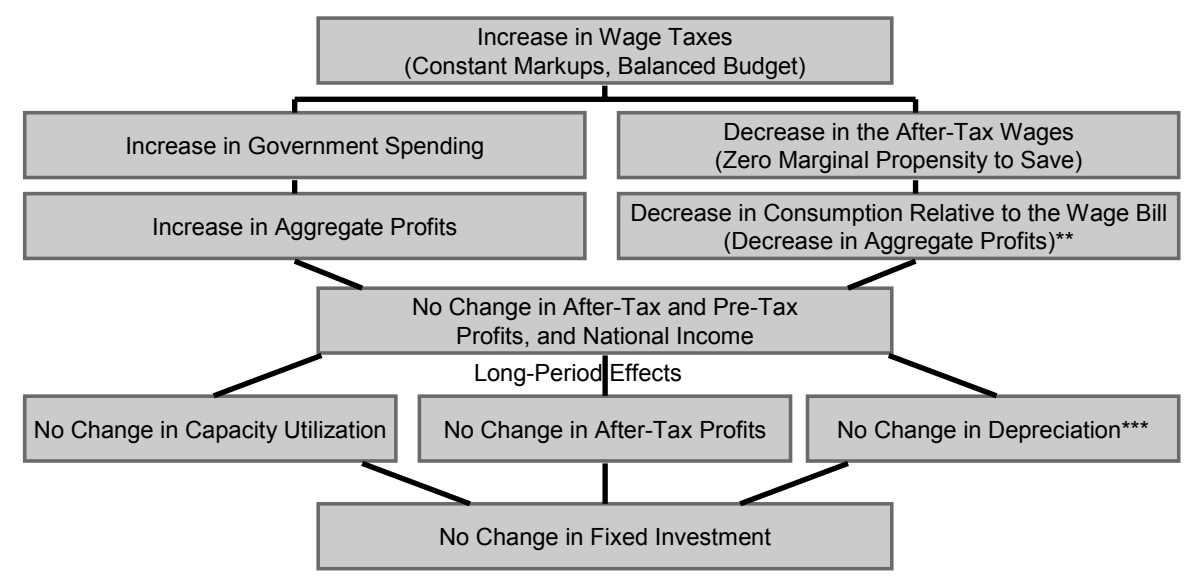

Note: ${ }^{*}$ The short-period incidence and effects of tax changes (where fixed investment expenditures are given by past investment decisions) depends on the government budget stance, the marginal propensity to save out of wages, the marginal propensity to consume out of profits, and the degree of tax shifting through changes in business price/cost markups. The long-period incidence and effects of tax changes (where fixed investment expenditure change in response to determinants) incorporates the impact of short-period effects on current period investment decisions and future investment expenditure. ${ }^{* *}$ If the marginal propensity to save out of wages is nonzero, then the decrease in wage consumption relative to the wage bill is dampened. The result is a traditional balanced budget effect where profits and national income rise. The rise in profits, and the increase in national income, capacity utilization, increase fixed investment in the long-run. ***If the price-cost markup decreases, as the wage tax is shifted, the wage bill and wage bill's share of national income increases. Through technical progress, the relative real cost of operating existing fixed capital rises and increases the relative rate of depreciation to existing fixed capital, and encourages investment in technological innovation. 
Figure Ib: The incidence and effects of taxation - An increase in profit tax (short-period effects)

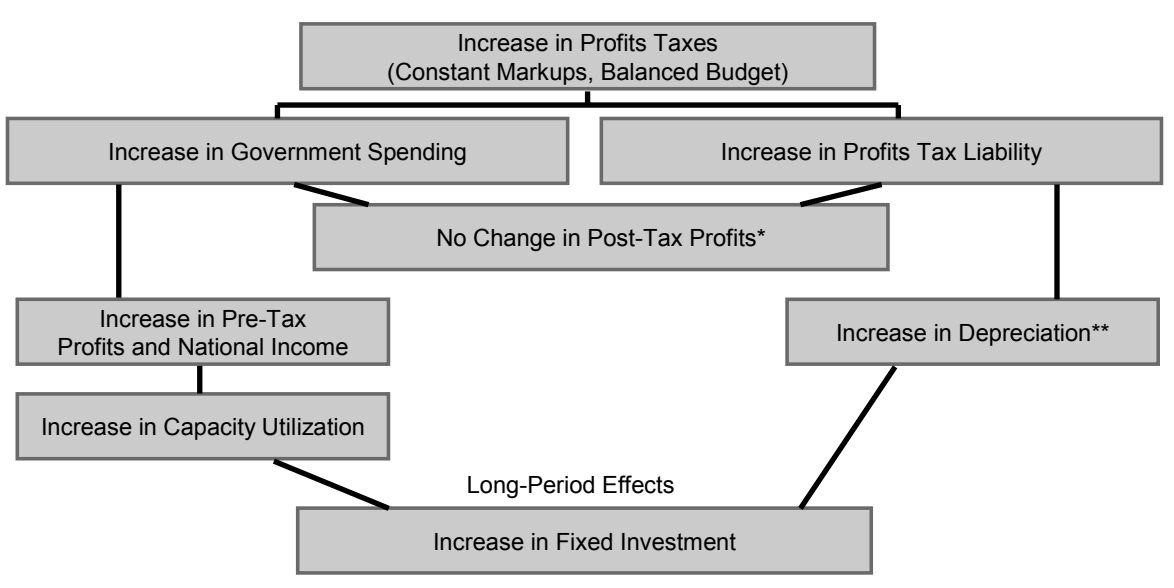

Note: *If the propensity to save out of wages is nonzero, the balanced budget increase in the profits tax increases the wage bill, reduces consumption relative to the wage bill, reduces after-tax profits, and dampens the increase in pre-tax profits and national income. ${ }^{* *}$ If the profits tax is shifted via an increase in price/cost markups, the wage share declines, the relative real cost of operating existing fixed capital declines, and depreciation declines, which discourages innovation.

Note that in the above balanced budget tax changes, the loss in post-tax profits due to increased profit taxes is completely offset by the increase in wage consumption relative to the wage bill, if the marginal propensity to consume out of profits and the marginal propensity to save out of wages are zero. If these propensities are nonzero, then the effects on pre-tax profits, national income and employment will be dampened. Similar results are obtained, if the increase in the profits tax is balanced against an increase in government purchases. In contrast, an increase in the wage tax, balanced against an increase in government purchases, will stimulate profits, national income and employment, if the marginal propensity to save out of wages is nonzero. As evidenced, the short-period effects of balanced budget tax changes are similar between the JMK and MK approaches. However, the MK approach explicitly links the tax changes to aggregate business profits, which, in turn, lead to long-period effects on investment and growth (see Figure Ia and Ib).

Functional finance and functional distribution of income. Both post-Keynesian approaches recognise the importance of functional finance. However, unlike the post-Keynesian (JMK) approach, the post-Keynesian (MK) approach emphasises the macroeconomic consequences of fiscally-induced changes in the functional distribution of income.

Tax shifting and incidence of taxation. Tax incidence is applied income distribution theory. Therefore, in studying the incidence of taxation it is important to specify on which theory of income distribution it is based. The post-Keynesian (JMK) approach does not specify its theory of income distribution. The post-Keynesian (MK) approach is explicit- 
ly based on the degree of monopoly theory of income distribution. The importance of tax shifting is recognised in the post-Keynesian (MK) approach and quite different macroeconomic effects follow depending on whether or not taxes are shifted.

Fiscal policy and growth. Both post-Keynesian approaches emphasise the role of fiscal policy in promoting a faster rate of growth. In the post-Keynesian (JMK) approach, the mechanism operates via the impact of functional finance on aggregate demand, which in turn, stimulates investment and raises the future productive capacity of the economy. The post-Keynesian (MK) approach uses an investment model to identify the drivers of growth and the channels through which balanced changes in the structure of taxation will have an impact on investment and growth.

Fiscal policy and innovation. The post-Keynesian (JMK) approach treats the rate of innovation as exogenous and does not identify any role for fiscal policy. The post-Keynesian $(\mathrm{MK})$ approach recognises that fiscal policy can stimulate innovation and then with a lagged impact on investment demand and growth, although its impact may be limited by a political innovation cycle (see Section 7 below).

Kalecki's original I937 tax formulation and its subsequent extension by Asimakopulos and Burbidge (1974) are both short period approaches in which the level of investment is determined by decisions taken in some earlier time period. They require to be incorporated in a dynamic model that seeks to identify the dynamic effects of fiscal policy as it impacts on investment, income distribution and growth. This we do in the next section.

In conclusion, both the JMK and MK approaches identify similar short-period effects of taxation. The JMK approach emphasises the effects of taxation on aggregate demand. The MK approach emphasises the effects of taxation on aggregate profits. By explicitly considering the affects of fiscal policy on aggregate profits, the MK approach allows for the dynamic, long-period, effects of profits to be explicitly considered. This becomes central to the greenhouse gas tax analysis in Section 6 below.

\section{Role of taxation in a Kaleckian growth model}

Having identified the most important differences between the two post-Keynesian approaches to fiscal policy, we now proceed to illustrate in more detail how changes in the structure of taxation with a balanced budget can impact on the rate of growth in a Kaleckian growth model. In particular, we show how taxation can have an impact on the rate of innovation.

Our starting point is Kalecki's (197I) theory of investment. Recall in the Kaleckian approach, the macroeconomic impact of taxation depends on: the relative marginal propensities to consume out of wages and profits; whether compensating changes exist in the government budget; the extent to which a tax change is shifted through changes in business mark-ups.

A critical element in the Kaleckian approach is the pricing behaviour of firms as this determines whether or not changes in the taxation of wages or profits result in changes in business mark-ups and in the distribution of income. Kalecki's theory of profits is made 
dynamic by linking taxation to his theories of profits, national income determination, income distribution, investment and growth. For Kalecki, everything is driven by what happens to investment. Changes in the structure of taxation today can affect investment and, thus, profits, tomorrow.

In Kalecki's theory of investment, taxation affects investment through three channels: the level of profits; the rate of depreciation; the capacity utilisation rate.

In turn, the effect of taxation on the level of profits operates through two channels (ignoring the foreign sector) as described before: the impact on the government budget position; the effect on income distribution.

For example, a balanced budget increase in the profits tax, in the manner described above, increases pre-tax profits, leaves after-tax profits unchanged, and increases national income if the marginal propensity to save out of wages is zero and the marginal propensity to consume out of profits is zero. The increase in national income, given the wage share, increases the wage bill and after-tax wages. If the marginal propensity to save out of wages is positive, the increase in after-tax wages will increase worker savings and will reduce consumption relative to wages. The decline in consumption relative to wages dampens the increase in pre-tax profits and reduces after-tax profits. ${ }^{2}$ The reduction in after-tax profits slows down the rate of growth in investment. The dampening effect is reduced if the profits tax is shifted via an increase in business price-costs mark-ups. The increase in the mark-ups reduces the wage share, dampens the increases in the wage bill and in worker savings. By dampening the increase in worker savings, the decrease in after-tax profits is dampened.

In contrast, a balanced budget increase in the wage tax will have no effect on pre-tax and post-tax profits and investment, if the marginal propensity to save out of wages is zero. If the marginal propensity to save out of wages is positive, the balanced budget increase in the wage tax will reduce worker savings, and increases pre-tax and post-tax profits and will increase investment. This increase is dampened to the extent that workers are able to shift the tax via a decrease in price-cost mark-ups. The decrease in price costs mark-ups increases national income and the wage bill and increases worker savings (reducing consumption relative to the wage bill) (see Figure Ia).

The rate of depreciation channel operates by altering the relative profitability of existing and new plant and equipment. With technological innovation through time, unit production costs associated with new capital goods decrease. This decrease in unit production costs shifts profits from old capital goods to new capital goods and increases the depreciation (and eventual obsolescence) of old capital goods. Kalecki (I97I) illustrates the depreciation effect, in a no tax world, by assuming that the profits captured by new investment embodying innovation, and lost to existing capital, are proportional to the difference between national income and profits (the wage bill). In a world with taxes, a balanced budget increase in the profits tax increases national income relative to post-tax profits, and, given the rate of technical progress, increases the profits captured by new investment encouraging

2 Likewise if the marginal propensity to consume out of profits is positive, the profits tax reduces consumption out of profits and dampens the increase in pre-tax and post-tax profits. 
investment, and reducing the profits captured by existing capital. This increases the rate of depreciation and obsolescence of existing capital. In contrast, a balanced budget increase in the wage tax, if the tax is not shifted, has no impact on national income relative to post-tax profits and no effect on depreciation or investment. This result is modified if the wage tax is shifted, via a decrease in the price-cost mark-up. The decrease in the mark-up increases the national income relative to post-tax profits, and accelerates the profits captured by innovation, encourages new investment, and decreases the profits captured by existing capital, accelerating its depreciation.

The economy's trend growth rate can be affected by changes in the structure of taxation when both the rate of capacity utilisation and business balance sheets matter in making capital investment decisions (Courvisanos 1996: 103 - IO6). Businesses are assumed to desire a certain rate of capacity utilisation. An increase in the rate of capacity utilisation above the desired level will accelerate expansions and dampen contractions in investment. A decrease in the rate of capacity utilisation below its desired level will dampen expansions and accelerate contractions in investment. As implied above, tax policy - by affecting the level of national income - can change the capacity utilisation rate and impact on investment decisions through this channel. For example, a balanced budget increase in the profits tax, when the marginal propensity to save out of wages is zero and the tax is not shifted, may increase investment by increasing national income and capacity utilisation (as in the JMK approach). Likewise, a balanced budget increase in the wage tax, when the propensity to save out wages is positive, can also increase national income and capacity utilisation (see Figure $\mathrm{Ib}$ ). Business balance sheets are incorporated by taking into account the firm's gearing ratio (the ratio of total liabilities to net worth) in order to capture the effect of increasing risk associated with investment (Kalecki 197I).

\section{Tax policy and the rate of innovation}

Having established the channels through which taxation can impact on investment and then through investment on the growth performance of the economy, we now introduce the link from investment to innovation. This will enable us to model the impact of tax policy changes on the rate of innovation and the dynamics of economic growth. The link is through the concept of the margin of obsolescence (Bloch et al. 2007). This concept relates to the decision rule on innovation. Investment in capital equipment that embodies best practice technology is a specific form of innovation. When firms make a decision to invest in plant and equipment that embodies new technological knowledge, whether that knowledge is related to products or processes, technological innovation (TI) takes place. Salter (1966) provided a seminal analysis of how technical change comes about through capital accumulation by focusing on the reverse side of innovation, that is, on technological obsolescence (TO).

Salter (I966: 54) defined TO as "plants which are sufficiently outmoded to be profitably replaced «. At any time, with both new and established knowledge, there is a spectrum of techniques used in production, ranging from sup to dates to soutmoded to sob- 
soleter. There are a number of factors that determine investment decisions in addition to TO. There is no inevitability that firms will automatically make investment decisions immediately to order the most up to date capital equipment. This may be due to financial constraints, wage costs, industry competitiveness (or lack of) and the level of technological flexibility (or inertia). By defining TO in terms of cost minimisation, Salter provides a method of identifying how and when firms find it profitable to invest in the TI embodied in the newest vintage capital equipment. Thus, technical change through TI becomes endogenous to the investment process.

Salter (1966: 74 - 5) argued that the >margin of obsolescence appears in a particular plant when the unit total (operating plus fixed overheads) costs of production using bestpractice capital equipment equals the unit operating (materials plus labour) costs of production of the oldest vintage capital equipment. On the smargin of obsolescencer the capital stock in a particular plant will be such that the implications, from a cost minimising perspective, to stay with the existing stock or invest in new equipment are identical. Salter's concept of the 'margin of obsolescencer can be linked to Kalecki's investment function through capacity utilisation on the basis that the smargin of obsolescencer can be alternatively identified as the point at which the total cost of new capacity equals the operating cost of existing outmoded capacity. Thus, when the total cost of new capacity becomes less than the operating cost of existing capacity, then existing `marginal capacity becomes TO. Salter's contribution is a clear decision-based convention or rule for when new TI should be introduced into the investment ordering process, subject to growth in demand.

Kalecki's (1954) degree of monopoly and TI are linked via four potentially quantifiable determinants of the degree of monopoly: the role of giant firms; the development of sales promotion through advertising, selling agents etc.; the influence of changes in the level of overhead costs in relation to prime costs; and the power of trade unions. From a theoretical perspective, TI should be incorporated into investment theory as innovation alters the incentive to invest by "changing the costs of production» or "altering product demand " (Bloch et al. 2007: 5). This is what Kalecki (1954: $17-18$ ) intended in his formulation of the degree of monopoly. "Changing the costs of production " is encapsulated in his identification of the "role of giant firms" (industry concentration and economies of scale), "changes in the level of overhead costs in relation to prime costs " and "the power of trade unions" (wage costs); while "product demand « is encapsulated in "the development of sales promotion" (product differentiation).

Kalecki's theory of income determination states that profits (capitalists' income) is primarily determined by capitalists' spending (investment) decisions in a previous time period. Businesses, being motivated by technological innovation to improve their degree of monopoly, increase their investment expenditures, and these investment expenditures generate additional aggregate profits. If the result of the innovation-induced investment is an increase in the degree monopoly, changes in income distribution will result. This may, in turn, subsequently affect future investment decisions through the profits, deprecation, or capacity utilisation effects, described earlier. 
Econometric results obtained by Laramie et al. (2004) show that both 'costs of production and 'product demand factors have influenced the degree of monopoly in UK manufacturing industry in recent years. These results endogenise the effects of technical change on the degree of monopoly. Technical change, in a monopoly-capital scenario, encourages investment and increases profits, the wage bill, and national income. However, if the benefits of technical change are captured exclusively by businesses, business mark-ups increase, the wage share will decrease, which further will increase the level of profits through a reduction in worker savings, but will dampen the investment-induced increase in the wage bill and national income. In addition, by reducing the real costs of production (increasing profits relative to national income), this income redistribution effect of technological change reduces the rate of depreciation and slows down the effect of technical change on new investment. Accordingly, we expect technologically induced changes in investment to move in cycles (for empirical evidence see Courvisanos/Verspagen 2004). The potential result is a contradiction between technologically induced growth and income distribution, which will give rise to cycles and to trends at below the level of full employment.

The Salter (1966)/Bloch et al. (2007) approach identifies a clear decision rule as to when a firm should adopt the most recent TI and undertake the necessary capital investment. We now consider how the introduction of taxation may influence this decision rule. Two conditions must hold. First, the introduction of taxation must increase the after-tax operating (material and labour) cost of existing capital equipment relative to the after-tax total cost of best-practice capital equipment, or, in the Salter (1966)/Bloch et al. (2007) terminology, raccelerate TO. Second, the introduction of taxation must increase the aftertax profitability of best-practice capital equipment relative to its pre-tax profitability, or, in Kaleckian terminology, increase the rate of depreciations. If these two conditions do not hold, then altering the structure of taxation has no role to play in influencing innovation, obsolescence or the rate of depreciation.

Assuming the two conditions above hold, the decision rule analysis is carried out in a time-dated framework, so that future costs and profits are expressed in discounted values. We begin by assuming that the firm is operating in time period $t$ with existing capital equipment and operating cost, $O C_{t}$. The firm has to decide whether to replace this existing equipment in time period $t+\tau$ with best-practice capital equipment with total cost $T C_{t+\tau}$. We assume that the operating and overhead costs of producing with best-practice capital equipment in $t+\tau$ are known with certainty in time period $t$. The Salter et al. decision rule applies when $T C_{t+\tau}=O C_{t}$. The operating cost of best-practice equipment, $O C_{t+\tau}$, must be less than $O C_{t}$, otherwise the decision rule will not be operational, i.e. $O C_{t+\tau}<O C_{t}$. However, overhead cost, $\mathrm{OHC}_{t+\tau}$, will be greater than $\mathrm{OHC}_{t}$ because of higher amortisation charges consequent on investment in best-practice capital equipment, i.e. $\mathrm{OHC}_{t+\tau}>\mathrm{OHC}_{t}, \mathrm{ce}-$ teris paribus.

The Salter et al. rule only relates to firms' costs and does not specify a profit condition. Thus, we specify a net profit $(P)$ condition that $P_{t+\tau}>P_{t}$. If the firm is applying the Kaleckian mark-up pricing rule, it follows that the mark-up, $k$, in $t+\tau$ has to rise, i.e. $k_{t+\tau}>k_{t}$. This is because the application of an unchanged mark-up to the lower operating cost, $O C_{t+\tau}$, (to 
determine price per unit of output) inevitably means that, with the higher overhead cost, $O H C_{t+\tau}$, profits in $t+\tau$ will be lower, i.e. $P_{t+\tau}<P_{t}$. Thus, the Salter et al. rule may be a necessary condition but is not a sufficient condition for TO. A necessary condition for TI to result in an increase in profits, thereby encouraging investment, is that price/cost mark-up on output associated with new equipment must increase. That is, the rate of depreciation must also be such that $P_{t+\tau}>P_{t}$. However, as indicated above, a rise in mark-ups has consequences for the distribution of income. The mark-up-induced decrease in the wage share dampens the effect of TI (TO of existing capital) on depreciation and investment. For this dampening effect to be small, the effect of the technological change on aggregate business mark-ups would have to be small (although perhaps large for some firms or industries).

We now consider how the introduction of taxation affects the above conditions. We illustrate the effect by reference to the introduction of a tax on the emission of greenhouse gases (GHG). We accept all the efficiency arguments in favour of GHG taxes to ensure that GHG emissions are priced to reflect the damage they cause (Stern 2006). We identify two Kaleckian categories of GHG tax (GT). The first is levied on GHG emissions associated with the production of production-goods (GTP), e.g. coal-fired electricity and fleet cars. The second is levied on the GHG emissions associated with the consumption of wagegoods (GTW), e.g. tourist travel and personal (non-luxury) cars.

If there is to be an increase in TO of high GHG emissions from existing capital, the gap between $O C_{t}$ and $O C_{t+\tau}$ has to widen. This can only occur in response to an increase in GTP or a shifted increase in GTW. This happens because operating costs (including wage costs and profit taxes), $O C_{t}$, are higher than $O C_{t+\tau}$, an increase in GTP and a shifted increase in GTW will have a relatively greater impact on $O C_{t}$ than on $O C_{t+\tau}$. A tax-induced stimulus to $\mathrm{TO}$ will be generated and the real costs associated with existing capital equipment at time period $\mathrm{t}$ will rise, thereby stimulating the rate of depreciation. However, GTW shifting implies an inverse relationship between the mark-up and GTW. Shifting of GTW will, therefore, result in a fall in the mark-up. With GTW shifting, the wage share increases, and the wage costs of operating existing capital rise relative to costs of operating new equipment. This in turn, will increase the relative profitability of new equipment and reduce the relative profitability of existing equipment, which will thus accelerate its depreciation.

With this modification, we examine first an increase in GTW. The effect of a shifted increase in GTW on the level of profits, $P_{t}$, will depend on the extent to which the shifting will increase the wage share, the wage bill, and workers' savings. When workers' savings are zero, a balanced budget tax change will have no effect on post-tax profits, $P_{t}$. It is, therefore, not inconceivable that the increase in GTW in time period $t$ would have no effect on $P_{t}$ although it is more likely that $P_{t}$ will fall, if GTW is shifted, and workers have a positive propensity to save. An increase in GTP and a shifted increase in GTW in time period t will give a kick-start to TI (and result in existing capital stock gradually becoming obsolete).

We now consider how the firm will respond to this stimulus and how fiscal policy can influence that response. In time period $t$ the firm recognises two consequences of these changes. First, it has a stronger financial incentive to replace its existing capital equipment; 
and, second, when GTW is shifted, its degree of monopoly has fallen, as witnessed by the fall in its mark-up. The firm must, therefore, seek to enhance its degree of monopoly, i.e. increase its mark-up, in order to make investment in TI financially viable in time period $t+\tau$. In either case, the firm attempts to shift these tax effects by accelerating the rate at which it innovates.

From the above analysis we can see that a tension exists between the effects of taxes on GTP and investment, and the effects of taxes on depreciation and investment. Balanced budget increases in GTP, when un-shifted and when workers' propensity to save is zero, have no effect on pre- or after-tax profits, but this increases operating costs and accelerates the margin of obsolescence of existing equipment while stimulating TI. Balanced budget increases in GTW, assuming workers' propensity to save is zero, when shifted, have no effect on after-tax profits, but instead increase national income through an increase in the wage share, and, like GTP, accelerate the margin of obsolescence of existing equipment.

There exists a balanced budget tax change that will accelerate the margin of obsolescence with positive effects on after-tax profits and the level of national income. Note that currently, no GHG taxes exist. Thus, the proposed balanced budget tax change is a combination of (i) an un-shifted increase in GTP and (ii) an un-shifted reduction in existing wage good taxes. Assuming no change in workers' savings and a non-zero positive capacity utilisation reaction coefficient, this tax package is conducive to innovation. Figure Ia and Ib summarise the tax change channels of influence to induce low GHG emissions technological innovation under specific conditions.

\section{Tax policy and the political economy of innovation}

Having established the conditions under which the government can use balanced changes in the structure of taxation to influence positively the margin of obsolescence, the question arises whether it will in fact actually do so. This parallels the question Kalecki posed in relation to the attainment of full employment in Political Aspects of Full Employment (PAFE) (Kalecki 1943). While he and Keynes had provided the policy tools and techniques that could ensure full employment, Kalecki, from a political economy perspective, recognised that sustained full employment in a capitalist economy would be unattainable. In the context of a capitalist policy solution, Harcourt (2006) refers to this as `The Kaleckian Dilemmar.

Kalecki (1943) identified the fears that capitalists have of full employment - loss of economic control and industrial control. Mair and Laramie (2002) develop this further by arguing that through the process of forming distributional coalitions, business interests can ensure that they do not lose these controls, thereby preventing a permanent and sustained attainment of full employment. Steindl (1979), Bhaduri and Steindl (1983) and Catley and McFarlane (198I) have provided empirical evidence of a Kaleckian-type political business cycle (PBC) in advanced industrial economies such as USA, UK and Australia. Courvisanos (2009) applies Kalecki's PAFE approach to innovation. Whereas in the original formulation of PAFE and its subsequent development, innovation played only a minor role, Courvisa- 
nos (2009) argued that analogous to PAFE, the spolitical aspects of innovation` (PAI) can also be identified in the recent experience of mature industrial economies.

Analogous to PAFE, the PAI approach identifies three fears that capitalists have with innovation:

- Loss of economic control with respect to their individual market power as innovation encourages new entrants that have the potential to reduce the incumbents' market share and ability to control the market.

To counter this threat, governments are persuaded by business interests to introduce various innovation policies to support incumbents, research and development (R\&D) subsidies to support incremental innovations, patent protection and other intellectual property rights.

- Loss of policy control as innovation becomes distributed across society through public institutions and public infrastructure that creates the national innovation system. To counter this threat, governments are persuaded by business interests to develop various strategies that support incumbents to regain some policy control, notably privatisation, public-private infrastructure programmes and public contracting.

- Loss of industrial control of the workforce if governments maintain industrial relations policies that reflect the full employment-type, high-union membership structures of the 1950 and r960s.

To counter this threat, governments are persuaded by business interests to introduce new industrial relations policies in the name of innovation aimed at supporting and encouraging flexibility in the workplace. This flexibility relates to the ability of firms to alter labour costs and structures when they introduce new process innovations that require less (and more flexible) labour.

\section{Kaleckian tax analysis: A pathway to common ground with NEC}

As we have shown, there are fundamental differences within the post-Keynesian approaches to fiscal policy. In favour of the Kaleckian approach, it has the major advantage of being a balanced budget approach and, consequently, satisfying the NEC cardinal rule of sound financer. Also, with its emphasis on the revenue side of the budget, the Kaleckian approach of balanced changes in the structure of taxation is more in tune with the supply side orientation of the NEC. Indeed, as we have shown in Section 6, a Kaleckian GHG tax operates by offering firms a fiscal incentiver which under certain conditions will accelerate the obsolescence of existing high GHG emissions plant and equipment and undertake new low GHG emissions technology investment.

The NEC has a morbid fear of inflation. To the extent that this is attributable to increased government spending, this fear is allayed by the balanced budget approach. The mantra of full employment does not arise in the Kaleckian approach. As early as 1943, Kalecki recognised that while full employment might be a technical possibility, the pressure 
of business interests would ensure it would be a political impossibility. Similarly, as we have shown in Section 7, while fiscal policy may have a stimulating effect on innovation, again the pressure of business interests will generate a political innovation cycle so that the full economic impact of innovation will never be achieved. NEC economists need not lie awake at nights worrying about the inflationary implications of Kaleckian fiscal policy.

A feature of the NEC approach, which finds a resonance in the Kaleckian approach is scrowding out . For the NEC, scrowding out is a physical concept in which the demands of the public sector for land, labour and capital elbow out the needs of the private sector, resulting in inflation and resource misallocation. The Kaleckian concept is more subtle and refers to the reaction of the business class to fears of a loss of political and economic control as the state `crowds out the private sector by extending its activities into spheres which had been the traditional preserve of the private sector (Kalecki 1943). But the NEC faces its own dilemma over Ricardian equivalence. Fiscal policy effectiveness can only be realised by abandoning Ricardian equivalence and the strict rationality assumption on which it is based.

Perhaps the most fundamental difference between the NEC and post-Keynesian (both varieties) approaches to fiscal policy is their stances on fiscal policy and growth. For the NEC fiscal policy has no contribution to make to growth and, at best, is a short-term palliative to be considered only when the economy is in the grips of serious recession. The post-Keynesian (JMK) approach recognises that fiscal policy contributes to growth by an expansion of aggregate demand resulting in an increase in investment, productive capacity and growth. But in the Keynesian ,functional finance approach this increased investment need not be anything more sophisticated than the purchase of shovels for the purpose of digging holes and filling them in again. Again, the Kaleckian approach is more subtle. It specifies the determinants of investment and identifies the channels through which changes in the structure of taxation can have an impact on these determinants. As we have shown in Section 6, the Kaleckian fiscal approach endogenises innovation so that fiscal policy can, under certain conditions, encourage an acceleration of low emissions technical progress, if the political aspects of innovation can to some extent be nullified.

\section{References}

Arestis, P., Sawyer, M. (2004): Re-examining Monetary and Fiscal Policies in the Twenty-first Century, Cheltenham: Edward Elgar.

Asimakopulos, A. (1978): Tax incidence, in: Eichner, A.S. (ed.), A Guide to Post Keynesian Economics, New York: M. E. Sharpe, 6I - 70.

Asimakopulos, A., Burbidge, J. (1974): The short-period incidence of taxation, in: Economic Journal, 84, $267-288$.

Bernanke, B. (2003): A perspective on inflation targeting: Remarks before the Annual Washington Policy Conference of the National Association of Business Economists, Washington, D.C., March 25.

Bernanke, B., Reinhart, V.R., Sack, B.P. (2004): Monetary policy alternatives at the zero bound: An empirical assessment, in: Brookings Papers on Economic Activity, 2, I - 78. 
Bhaduri, A., Steindl, J. (1983): The rise of monetarism as a social doctrine, Thames Papers in Political Economy, Autumn.

Bloch, H., Mangano, M., Courvisanos J. (2007): Innovation and investment: Technological obsolescence in Australian manufacturing, Centre for Research in Applied Economics, Curtin University of Technology Working Paper Series, No. 07-02, April.

Catley, R., McFarlane, B.J. (198I): Australian Capitalism in Boom and Depression, Chippendale, NSW: Alternative Publishing Cooperative.

Courvisanos, J. (1996): Investment Cycles in Capitalist Economies: A Kaleckian Behavioural Contribution, Cheltenham: Edward Elgar.

Courvisanos, J. (2009): Political aspects of innovation, Research Policy, URL: http://dx.doi. org/IO.IOI6/j.respol.2009.04.00I (hard copy forthcoming).

Courvisanos, J., Verspagen, B. (2004): Innovation and investment in capitalist economies 1870 - 2000: Kaleckian dynamics and evolutionary life cycles, in: Wray, L.R., Forstater, M. (eds.), Contemporary Post Keynesian Analysis, Cheltenham: Edward Elgar, 205 - 226.

Harcourt, G.C. (2006): The Structure of Post-Keynesian Economics, Cambridge: Cambridge University Press.

Kalecki, M. (1937): A theory of commodity, income and capital taxation, in: Economic Journal, 47, 444-450.

Kalecki, M. (1943): Political aspects of full employment, in: Political Quarterly, XIV( 4), $347-356$.

Kalecki, M. (1954): Theory of Economic Dynamics, London: Unwin University Books.

Kalecki, M. (197I): Entrepreneurial capital and investment, in: Kalecki, M. (ed.), Selected Essays on the Dynamics of the Capitalist Economy, Cambridge: Cambridge University Press.

Krugman, P. (2005): Is fiscal policy poised for a comeback? in: Oxford Review of Economic Policy, $2 \mathrm{I}(4), 5 \mathrm{I} 5-523$.

Laramie, A.J., Mair, D., Reynolds, P.J. (2004): Kalecki's theory of income distribution: The answer to a maiden's prayer?, in: Wray, L.R., Forstater, M. (eds.), Contemporary Post Keynesian Analysis, Cheltenham: Edward Elgar, $227-248$.

Laramie, A., Mair, D. (2000): A Dynamic Theory of Taxation: Integrating Kalecki into Modern Public Finance, Cheltenham: Edward Elgar.

Lerner, A.P. (1943): Functional finance and the federal debt, in: Social Research, IO(I), $38-57$.

Mair, D., Laramie A.J. (2002): Full employment: Gift horse or Trojan horse?, in: Review of Social Economy, LX(4), $567-594$.

Salter, W.E.G. (1966): Productivity and Technical Change, Cambridge: Cambridge University Press.

Steindl, J. (1979): Stagnation theory and stagnation policy, in: Cambridge Journal of Economics, $3, \mathrm{I}-\mathrm{I} 4$.

Stern, N. (2006): The Economics of Climate Change, Cambridge: Cambridge University Press.

Tcherneva, P. (2008): The return of fiscal policy: Can the new developments in the New Economic Consensus be reconciled with the Post-Keynesian view?, The Levy Economics Institute, Bard College, USA, Working Paper, No. 539. 
